\title{
Growth and nutrients uptake in Euterpe edulis Martius inoculated with arbuscular mycorrhizal fungi ${ }^{1}$
}

\author{
Sandro Lucio Silva Moreira², Paulo Prates Júnior², \\ Raphael Bragança Alves Fernandes², Ana Catarina Monteiro Mori da Cunha ${ }^{3}$, André Narvaes da Rocha Campos ${ }^{4}$
}

\section{ABSTRACT}

Euterpe edulis Martius is one of the endangered species of the Brazilian Atlantic Forest which presents low germination rate and slow seedling growth. Arbuscular mycorrhizal fungi $(\mathrm{AMF})$ are known by their symbiosis with plants, promoting an increase of water and nutrientes uptake. This study aimed at evaluating the effect of AMF inoculation on the initial growth (6 months) and nutrients uptake in E. edulis seedlings. Treatments consisted of the inoculation of pre-germinated seeds with AMF spores collected from three sites (forest, Juçara and crop), as well as a control with no inoculation. Seedlings growth, number of AMF spores in the substrate and uptake of the $\mathrm{N}, \mathrm{P}, \mathrm{K}, \mathrm{Ca}$ and $\mathrm{Mg}$ macronutrients in plant tissues were analyzed. Inoculation with AMF improved the initial growth of seedlings, regardless of the source of inoculum used in the experiment, and the inoculation with material collected from rhizosphere increased the shoot and root dry biomass of seedlings by $43 \%$ and $61 \%$, respectively. Inoculation with AMF provided a greater accumulation of all nutrients assessed in the shoot and root of seedlings, especially when spores were collected at the Juçara site. Inoculation with AMF is a promising strategy to improve the spread of this species.

KEY-WORDS: Euterpe edulis Martius; Atlantic Forest; conservation of endangered species.

\section{INTRODUCTION}

The Atlantic Forest is recognized as one of the most threatened biodiversity hotspots, with only $\sim 12 \%$ of its original coverage remaining (Ribeiro et al. 2009). This deforestation process transformed the landscape into a mosaic of advanced stages of forest fragmentation (Andreazzi et al. 2009) that, when combined with low functional connectivity, result in biodiversity loss.

\section{RESUMO}

Crescimento e absorção de nutrientes em palmeira Juçara inoculada com fungos micorrízicos arbusculares

A palmeira Juçara é uma das espécies da Floresta Atlântica ameaçadas de extinção, a qual apresenta baixo percentual de germinação e crescimento lento de mudas. Os fungos micorrízicos arbusculares (FMA) são reconhecidos pela simbiose com plantas, favorecendo o aumento da absorção de água e nutrientes. Objetivouse avaliar o efeito da inoculação de FMA no crescimento inicial (6 meses) e nutrição de mudas de palmeira Juçara. Os tratamentos consistiram da inoculação de sementes pré-geminadas com esporos de FMA coletados em três ambientes (mata, Juçara e cultivo agrícola), bem como de controle não inoculado. Foram analisados o crescimento das mudas, número de esporos de FMA no substrato e absorção dos macronutrientes N, P, K, Ca e Mg nos tecidos vegetais. A inoculação com FMA melhorou o desenvolvimento inicial das mudas, independentemente da origem do inóculo utilizado, e a inoculação com material coletado na rizosfera incrementou a biomassa seca da parte aérea e da raiz das mudas em $43 \%$ e $61 \%$, respectivamente. A inoculação com FMA proporcionou maior acúmulo de todos os nutrientes avaliados na parte aérea e no sistema radicular das mudas, principalmente quando se utilizaram esporos coletados no ambiente Juçara. A inoculação com FMA é uma estratégia promissora para melhorar a propagação dessa espécie.

PALAVRAS-CHAVE: Euterpe edulis Martius; Floresta Atlântica; conservação de espécies ameaçadas.

Among the endangered species, Euterpe edulis Martius (Arecaceae) stands out (Brasil 2008 and 2014, Sgrott et al. 2012). This is a typical species from the Brazilian Atlantic Forest that occurs mainly in remote and well-conserved areas or areas protected by law (Cembraneli et al. 2009).

E. edulis is an important forest species that serves as food for local wildlife, besides being a valuable resource for some traditional rural

1. Manuscript received in Jan./2016 and accepted for publication in Jun./2016 (http://dx.doi.org/10.1590/1983-40632016v4639547).

2. Universidade Federal de Viçosa, Viçosa, MG, Brazil. E-mails: sandro_smoreira@hotmail.com, junior_prates2005@yahoo.com.br,raphael@ufv.br.

3. Instituto Federal de Alagoas, Satuba, AL, Brazil.E-mail: catarina_mori@yahoo.com.br.

4. Instituto Federal do Sudeste de Minas, Rio Pomba, MG, Brazil.E-mail: andre.campos@ifsudestemg.edu.br. 
communities which use its stalk, heart of palm, fruits, leaves and seeds (Barroso et al. 2010, Fanelli et al. 2012). Therefore, E. edulis presents ecological, economic and social relevance. However, because of deforestation and intensive illegal exploitation, for the extraction of heart of palm (Calvi \& Pinã-Rodrigues 2005, Favreto et al. 2010), the remaining population has been greatly reduced (Galetti \& Fernandez 1998). In addition, its long cycle and difficult propagation are factors that contribute to hamper the repopulation of forest areas with this species.

The palm has only one stalk (trunk) and produces tillers. Thus, the heart of palm extraction involves the harvest of the plant, which takes six to ten years to produce seeds (Carvalho 1994). In addition, seed germination is slow, requiring three to six months to emerge from the substrate (Lorenzi et al. 1996). Therefore, repopulation strategies are required for its management and sustainable use (Oliveira Júnior et al. 2010).

Despite its high cost, the use of seedlings in revegetation practices is preferred, due to a higher success rate than in broadcast seeding. Thus, studies related to planting, management and seedling production techniques, as well as to ecology and growth dynamic of this palm, have been demanded for more sustainable exploitation and reintroduction practices.

The arbuscular mycorrhizal fungi (AMF Glomeromycota) are obligate symbionts associated with plant roots (Parniske 2008). They have potential to increase the nutrients uptake and to stimulate plant growth (Douds Jr. et al. 2008.). Additionally, they have potential to reduce the effects of biotic and abiotic stress factors, improving soil quality. AMF have increasingly been considered essential for the sustainable management of agricultural systems (Gianinazzi et al. 2010).

The beneficial effects of AMF for plant growth are well reported and mainly related to rises in $\mathrm{P}$ absorption (Smith \& Read 1997), being more evident in conditions of low nutrient availability (Parniske 2008). In addition, AMF are capable of increasing tolerance to abiotic stresses, such as drought, salinity and heavy metal contamination (Gianinnazzi et al. 2010). Moreover, they can compete with soil pathogens for infection sites and activate the plants defense responses (Tahat et al. 2010, Wehner et al. 2010). Thus, the knowledge on the ecology of these fungi and their association with different species are very important when the target is the sustainable management of native plants (Antoniolli et al. 2002).

Evidences indicate that the E. edulis naturally occuring in the Atlantic Forest of the Minas Gerais State is associated with mycorrhizal fungi (Medina et al. 2012), and fungi inoculation can increase the biomass accumulation of the palm tree after transplanting to the field (Sgrott et al. 2012). Therefore, the presence of these fungi is widely desired by farmers and agriculture and environment professionals as a potential alternative to reduce the use of chemicals, improve the success rates for seedlings in the field and reach a more sustainable production.

Regarding the farmers, it should be highlighted that the possibility of AMF inoculants production can be obtained through accessible procedures, such as the on-farm method (Douds Jr. et al. 2008), which favors the transplanting of colonized seedlings to the field. The on-farm method is an important and environmentally friendly social technology, because it favors not only the reduction of inputs, but also increases plant growth (Czerniak \& Stümer 2014) and the farmers autonomy in the inoculant production.

Studies about growth and nutrition of E. edulis inoculated with AMF, such as the one by Sgrott et al. (2012), are scarce. However, the expected benefits of seedlings inoculation can provide important contributions to the success of a more sustainable use of these palm trees, contributing to the commercial and non-commercial seedlings production.

AMF symbiosis may improve reintroduction practices in forest areas, thereby reducing the extinction threat of $E$. edulis. Thus, this study aimed at evaluating the effects of AMF inoculation directly obtained from field collection on the growth and plant nutrition of $E$. edulis seedlings.

\section{MATERIAL AND METHODS}

The experiment was carried out from April to December 2012, at the Instituto Federal do Sudeste de Minas, in Rio Pomba, Minas Gerais State, Brazil. All chemical analyzes were performed at the Universidade Federal de Viçosa, in Viçosa, also in the Minas Gerais State.

The germination of E. edulis seeds was performed according to Martin \& Souza (2009). Seeds were collected from a forest fragment in Rio Pomba 
( $21^{\circ} 15^{\prime} 26^{\prime \prime} \mathrm{S}, 43^{\circ} 06^{\prime} 35^{\prime \prime} \mathrm{W}$ and $456 \mathrm{~m}$ of altitude). Neither seeds found on the ground nor seeds from isolated palm trees were used, respectively because they could have reduced germination or could be produced by selfing, which generally results in inbreeding depression (Bovi \& Cardoso 1978). After collecting, seeds were pulped, immersed in water for two days (Bovi 1998), mechanically scarified and sown in trays with sand previously sterilized twice in an autoclave $\left(1 \mathrm{~h}\right.$ at $\left.121^{\circ} \mathrm{C}\right)$.

AMF spores were obtained from composite soil samples from five randomly selected subsamples collected in three different sites of Rio Pomba. Two collection sites were selected inside a fragment of secondary Atlantic Forest (80 years old) previously used for coffee cultivation with low (forest site $21^{\circ} 14^{\prime} 27^{\prime \prime} \mathrm{S}, 43^{\circ} 09^{\prime} 42^{\prime \prime} \mathrm{W}$ and $484 \mathrm{~m}$ of altitude) and high (Juçara site - $21^{\circ} 13^{\prime} 16^{\prime \prime}$ 'S, 43 $03^{\circ}$ '53"W and $559 \mathrm{~m}$ of altitude) incidence of E. edulis. The third collection site was assigned in a field of annual crops (crop site - $21^{\circ} 14^{\prime} 301^{\prime \prime} \mathrm{S}, 43^{\circ} 09^{\prime} 32^{\prime \prime} \mathrm{W}$ and $457 \mathrm{~m}$ of altitude), cultivated with maize in the $\mathrm{R} 2$ reproductive stage (milky grain). The crop site had been submitted to agroecological practices in the previous three years, after conventional management for 40 years, with annual input of N-P-K (8-28-16) fertilization, pre-emergent herbicides and insecticides.

Soil subsamples were randomly collected at $0-10 \mathrm{~cm}$ depth in five sampling points, in forest and crop sites. In the Juçara site, soil sampling was carried out at $0-20 \mathrm{~cm}$ depth and close to the $E$. edulis stem (within a radius of $30 \mathrm{~cm}$ ), aiming to obtain an influence area of roots. A minimal distance of $15 \mathrm{~m}$ among different sampling points in this site was considered.

Composite soil samples were homogenized and $50 \mathrm{~g}$ were used for the spore extraction (Gerdemann \& Nicolson 1963). Soil samples were transferred to a $1 \mathrm{~L}$ plastic container, which had its volume filled with distilled water, and manual stirring was performed. After approximately $1 \mathrm{~min}$ for settling the coarser particles, suspension was poured onto a set of overlaid sieves with mesh sizes of $0.425 \mathrm{~mm}, 0.106 \mathrm{~mm}$ and $0.053 \mathrm{~mm}$. Using a wash bottle, the material retained between $0.106 \mathrm{~mm}$ and $0.053 \mathrm{~mm}$ meshes was transferred to a $50 \mathrm{~mL}$ centrifuge tube, which was centrifuged at $3,000 \mathrm{rpm}$, during $3 \mathrm{~min}$. The supernatant was discarded, and in the tube was added a $60 \%$ sucrose solution, followed by resuspension of the settled material by stirring.
The material was centrifuged again at 2,000 rpm, for $2 \mathrm{~min}$, and the supernatant was passed through a $0.053 \mathrm{~mm}$ sieve. The material retained on the sieve was washed with distilled water to remove sucrose residues. The spores retained in the sieve were collected and the count was performed using channeled Petri dishes.

Seeds were transplanted after 55 days of germination to $1.7 \mathrm{dm}^{3}$ plastic bags containing unsterilized substrate consisting of a mix of soil from the $\mathrm{C}$ horizon, bovine manure and sand (2:1:0.5 proportion in volume). This substrate is similar to the common seedling substrate used by producers in the region. Substrate was submitted to chemical analysis (water $\mathrm{pH} ; \mathrm{P}$ and $\mathrm{K}$, Mehlich 1 extractor; $\mathrm{Ca}, \mathrm{Mg}$ and $\mathrm{Al}, \mathrm{KCl} 1 \mathrm{~mol} \mathrm{~L}^{-1}$ extractor; $\mathrm{H}+\mathrm{Al}$, SMP extractor), and the following results were obtained: $\mathrm{pH}=6.83 ; \mathrm{P}=96.1 \mathrm{mg} \mathrm{dm}^{-3} ; \mathrm{K}=$ $288 \mathrm{mg} \mathrm{dm}^{-3} ; \mathrm{Ca}=3.9 \mathrm{cmol}_{\mathrm{c}} \mathrm{dm}^{-3} ; \mathrm{Mg}=2.6 \mathrm{cmol}_{\mathrm{c}} \mathrm{dm}^{-3}$; $\mathrm{Al}=0 \mathrm{cmol}_{\mathrm{c}} \mathrm{dm}^{-3} ; \mathrm{H}+\mathrm{Al}=7.7 \mathrm{cmol}_{\mathrm{c}} \mathrm{dm}^{-3} ; \mathrm{SB}=$ $7.24 \mathrm{cmol}_{\mathrm{c}} \mathrm{dm}^{-3}$; effective CEC (t) $=7.24 \mathrm{cmol}_{\mathrm{c}} \mathrm{dm}^{-3}$; total $\mathrm{CEC}^{\mathrm{c}}(\mathrm{T}): 14.94 \mathrm{cmol}_{\mathrm{c}} \mathrm{dm}^{-3} ; \mathrm{V}(\%)=48.5 \%$.

In the inoculation of $E$. edulis seedlings, a mixture containing 3,500 spores from each of the three sites (forest, Juçara, crop) were first homogenized in a $100 \mathrm{~g}$ of autoclaved sand. In each plastic bag containing the substrate, a hole of $6 \mathrm{~cm}$ depth was opened and completed with one E. edulis seedling with $10 \mathrm{~g}$ of sand inoculated with spores. A control treatment was prepared with E. edulis seedling plus autoclaved sand (without spores).

The experiment was set in a completely randomized design, with four treatments (forest, Juçara, crop, control), corresponding to different inoculum sources, and 10 replications, and was carried out in a greenhouse, during six months. In the beginning, all treatments were randomized, and randomization was repeated every month. During the experiment, the experimental units were irrigated daily to ensure adequate substrate moisture for plant development.

At the end of the experiment, the following data were collected: diameter, shoot height and number of leaves. After that, seedlings were harvested to estimate shoot and root biomass (dry matter) and to calculate the shoot/root ratio. Thin roots $(<2 \mathrm{~mm}$ in diameter) were also sampled $(0.5 \mathrm{~g})$ to estimate the percentage of mycorrhizal colonization (Medina et al. 2012). The postcultivation substrate was homogenized and a 
$50 \mathrm{~g}$ subsample was submitted to spores extraction (Gerdemann \& Nicolson 1963).

Dry shoot and root samples were ground and submitted to nitropercloric digestion for $\mathrm{P}, \mathrm{K}, \mathrm{Mg}$ and $\mathrm{Ca}$ evaluation. The total $\mathrm{N}$ content was determined only in the shoot, through sulfuric acid digestion and subsequent Kjeldahl distillation. Analytical procedures involved in digestion and nutrient determinations followed the recommendations by Embrapa (2009).

The results were submitted to analyses of variance (Anova), after normality verification by the Shapiro-Wilk test, and the average levels of the significant treatments were compared by the Tukey test, at $5 \%$. The analysis was performed in the statistical package R, version 3.2.1 (R Core Team 2014).

\section{RESULTS AND DISCUSSION}

Analysis of variance (Anova) showed differences among treatments, and inoculation with AMF enhanced growth of E. edulis seedlings. Regardless of the inoculum source, inoculated seedlings showed higher shoot and root dry matter production, stem diameter and number of leaves than the control (Table 1). Differences among treatments were not found only for shoot height and shoot/root ratio, at the end of the experiment.

A better seedlings growth may indicate a greater capacity for survival, which is considered essential in a conservation program or even in the reintroduction of the species in degraded areas. Martins-Corder \& Saldanha (2006) associated the amount of leaves in E. edulis seedlings with the survival of seedlings in the field.

The important role that can be played by the AMF in the development of E. edulis was also verified by Sgrott et al. (2012), who observed increases in total biomass and number of leaves after 12 and 24 months of seedlings inoculation with a mixture of AMF species (Acaulospora koskei, Scutellospora heterogama, Gigaspora albida, Rhizophagus clarum). Gains in plant height, stem diameter and dry matter production after inoculation with seven different AMF species were also obtained for Euterpe oleracea Mart., another palm tree species from the same family (Chu 1999).

Gains in growth of palm trees associated with AMF inoculation may be related to the greater volume of soil explored by roots of colonized plants, thus allowing greater absorption of water and nutrients by plants (Silva et al. 1998). The association with AMF becomes even more relevant for E. edulis, which presents a root system with many thick roots, what may indicate high mycorrhizal dependence.

The absence of differences among the variables linked to the growth of seedlings, regarding the inoculum source, indicates that all evaluated sites (forest, Juçara, crop) have the potential to promote mycorrhizal colonization, since an appropriate number of spores is provided. As the number of spores added in all treatments was standardized, the amount used was adequate to ensure benefits to the growth of seedlings.

The evaluation of mycorrhizal colonization allowed the identification of only some mycorrhizal structures in the few thicker secondary roots obtained. It was not possible to perform the visualization of fungal structures in rootlets and the measurement of the colonization percentage. The difficulty in quantifying this colonization may be related to the morphological and anatomical root characteristics of E. edulis, which features underdeveloped cortex in young roots (Gazey et al. 1992) and high incidence of sclerenchyma in the cell wall (Sgrott et al. 2012). The

Table 1. Effect of inoculation with arbuscular mycorrhizal fungi spores from different sites (treatments) on the growth of Euterpe edulis Martius seedlings, after six months of cultivation.

\begin{tabular}{|c|c|c|c|c|c|}
\hline \multirow{2}{*}{ Growth attribute } & \multicolumn{5}{|c|}{ Treatment } \\
\hline & Forest & Juçara & Crop & Control & CV (\%) \\
\hline Shoot dry matter (g) & $0.50 \mathrm{a}$ & $0.56 \mathrm{a}$ & $0.53 \mathrm{a}$ & $0.39 \mathrm{~b}$ & 14.04 \\
\hline Root dry matter (g) & $0.19 \mathrm{a}$ & $0.21 \mathrm{a}$ & $0.20 \mathrm{a}$ & $0.13 \mathrm{~b}$ & 21.56 \\
\hline Shoot/root ratio & $2.69 \mathrm{a}$ & $2.69 \mathrm{a}$ & $2.76 \mathrm{a}$ & $3.02 \mathrm{a}$ & 20.97 \\
\hline Stem diameter $(\mathrm{mm})$ & $6.45 \mathrm{a}$ & $6.75 \mathrm{a}$ & $6.48 \mathrm{a}$ & $5.34 \mathrm{~b}$ & 10.09 \\
\hline Shoot height $(\mathrm{cm})$ & $16.65 \mathrm{a}$ & $8.25 \mathrm{a}$ & $17.05 \mathrm{a}$ & $16.15 \mathrm{a}$ & 10.54 \\
\hline Number of leaves & $21.40 \mathrm{a}$ & $21.90 \mathrm{a}$ & $21.00 \mathrm{a}$ & $17.50 \mathrm{~b}$ & 9.64 \\
\hline
\end{tabular}

Means followed by the same letter in the row do not differ according to the Tukey test at $5 \%$. CV: coefficient of variation. 
small diameter of the seedlings roots also contributed to the quantification difficulty, similarly to the mychorrizal colonization evaluation in peach palm roots (Silva et al. 1998). Studies that aim to identify more clearly the mycorrhizal colonization by AMF in E. edulis roots should therefore consider a longer cultivation time of seedlings, in order to enable the production of more roots with higher diameter.

The analysis of the substrate used for the seedlings cultivation showed greater presence of MFA spores in forest and Juçara treatments, at the end of the six months of the experiment (Figure 1).

Substrate inoculated with AMF from the crop site presented the smallest number of spores, with similar magnitude to that observed in the non-

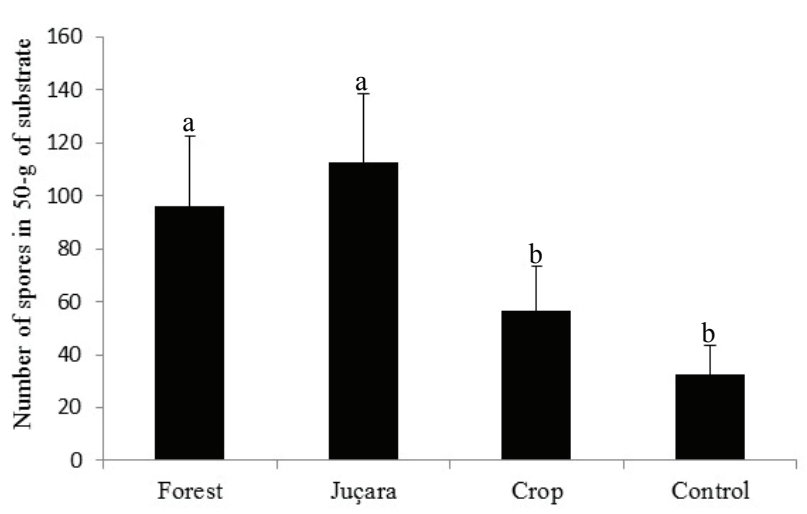

Figure 1. Number of spores in the substrate used in the experiment, after six months of Euterpe edulis growing in a substrate inoculated or not (control) with different AMF sources. Means followed by the same letter do not differ according to the Tukey test at $5 \%$. Bars indicate the mean standard deviation. inoculated control treatment. Considering the fact that inoculated treatments received the same amount of spores, the sites with typical vegetation of the Atlantic Forest (forest and Juçara), and therefore less anthropized environments, may provide more viable spores and/or more survivability in a new substrate. The crop cultivation, apparently, may hamper spores viability or reduce the diversity of AMF species, what, in turn, makes AMF inoculum more subjected to the constraints imposed by a new substrate. The presence of spores in the control treatment can be explained by the possible presence of AMF in the original substrate.

There are evidences that agricultural systems can select some AMF species, reducing the diversity of the fungi population (Douds Jr. \& Millner 1999). Therefore, less disturbed environments present the potential to offer a greater diversity of AMF species for inoculation, what can be considered an advantageous aspect, given the possibility of complementary effects on soil exploitation (Maherali \& Klironomos 2007). Different AMF may have different strategies used for root colonization and, consequently, specificity to the host plants (Parniske 2008).

Nutrients accumulation in shoot and root of E. edulis seedlings was affected by fungi inoculation. The use of AMF spores provided greater nutrients accumulation in $E$. edulis seedlings after six months of cultivation, both in the shoot and root system (Table 2).

The control treatment presented the lowest nutrients contents, indicating the importance of inoculation for the mineral nutrition of plants, what

Table 2. Nutrient accumulation in shoot and root of Euterpe edulis seedlings after arbuscular mycorrhizal fungi inoculation with spores from different sites.

\begin{tabular}{|c|c|c|c|c|c|}
\hline \multirow{2}{*}{ Nutrient } & \multicolumn{5}{|c|}{ Treatment } \\
\hline & Forest & Juçara & Crop & Control & $\mathrm{CV}(\%)$ \\
\hline & & & $\left(\mu \mathrm{g}\right.$ plant $\left.{ }^{-1}\right)$ & & \\
\hline $\mathrm{N}$ & $112.05 \mathrm{~b}$ & $122.30 \mathrm{a}$ & $110.94 \mathrm{bc}$ & $91.77 \mathrm{c}$ & 15.1 \\
\hline $\mathrm{P}$ & $6.17 \mathrm{ab}$ & $7.13 \mathrm{a}$ & $7.01 \mathrm{a}$ & $5.63 \mathrm{~b}$ & 16.1 \\
\hline $\mathrm{K}$ & $81.88 \mathrm{ab}$ & $100.25 \mathrm{a}$ & $87.27 \mathrm{ab}$ & $65.95 \mathrm{~b}$ & 24.9 \\
\hline $\mathrm{Ca}$ & $43.00 \mathrm{a}$ & $44.23 \mathrm{a}$ & $48.61 \mathrm{a}$ & $31.88 \mathrm{~b}$ & 18.3 \\
\hline $\mathrm{Mg}$ & $10.78 \mathrm{ab}$ & $11.22 \mathrm{a}$ & $11.56 \mathrm{a}$ & $8.64 \mathrm{~b}$ & 17.5 \\
\hline & & & $\left(\mu\right.$ g plant $\left.^{-1}\right)$ & & \\
\hline$P$ & $2.95 \mathrm{bc}$ & $3.68 \mathrm{ab}$ & $4.09 \mathrm{a}$ & $2.47 \mathrm{c}$ & 23.7 \\
\hline $\mathrm{K}$ & $23.58 \mathrm{ab}$ & $21.61 \mathrm{bc}$ & $29.37 \mathrm{a}$ & $17.35 \mathrm{c}$ & 21.0 \\
\hline $\mathrm{Ca}$ & $2.97 \mathrm{bc}$ & $4.04 \mathrm{ab}$ & $5.18 \mathrm{a}$ & $2.02 \mathrm{c}$ & 40.3 \\
\hline $\mathrm{Mg}$ & $2.34 \mathrm{ab}$ & $3.07 \mathrm{a}$ & $2.69 \mathrm{a}$ & $1.67 \mathrm{~b}$ & 31.5 \\
\hline
\end{tabular}

Means followed by the same letter in the row do not differ according to the Tukey test at $5 \%$. CV: coefficient of variation. 
may result in better quality of seedlings and improved survival rates in the field. For shoot, the content of all nutrients after inoculation with spores from the Juçara site was higher than that obtained in the control treatment. The nutrient contents observed with spores from the forest treatment exceeded those obtained in the control treatment for $\mathrm{N}$ and $\mathrm{Ca}$, and the crop treatment surpassed the control treatment, in relation to the contents of $\mathrm{P}, \mathrm{Ca}$ and $\mathrm{Mg}$.

Considering the accumulation of nutrients by the root system of E. edulis seedlings, in relation to the control, the greatest absorption for all macronutrients was related to spores collected from the crop and Juçara sites, except for the K accumulation in this last treatment. In seedlings cultivated with spores from the forest site, $\mathrm{K}$ was the nutrient that showed the greatest accumulation, when compared to the control. Higher nutrient accumulation in plant tissues suggests a greater potential for survival and higher seedlings quality. In this aspect, the use of inoculant with AMF presents beneficial effects for the seedlings growth and nutrition, resulting in more vigorous plants and obtained from a low-cost strategy of seedlings production. This is even more significant in plants such as E. edulis, since it is an endangered species, with germination and stablishment difficulties in the field. Survival rate increase is considered one of the key factors for the success of the species reintroduction and conservation, as well as for its commercial plantation.

Studies that have evaluated the effects of AMF inoculation on the mineral nutrition of the Euterpe genus are scarce. Among them, Chu (1999) found a positive effect in the uptake and accumulation of $\mathrm{N}$, $\mathrm{P}, \mathrm{K}, \mathrm{Ca}, \mathrm{Mg}$ and $\mathrm{Zn}$ in Euterpe oleracea, after nine months of inoculation with Scutellospora gilmorei, in comparison with the non-inoculated control treatment.

In a scenario of better use of the potential of AMF associated with E. edulis (Sgrott et al. 2012), the increase in seedlings production may alleviate the reduction of populations of this palm tree, potentially making crop areas an important strategy for the conservation of the species (Favreto et al. 2010). Seedlings production may also be configured as an important source of income for small farmers (Cembraneli et al. 2009). Thereby, all these initiatives can contribute to the reintroduction of this threatened species in the Atlantic Forest, including its commercial exploitation, particularly if associated with the on-farm method for the AMF inoculant production.

\section{CONCLUSIONS}

1. Inoculation with arbuscular mycorrhizal fungi enhances the initial development of Euterpe edulis seedlings.

2. Although the inoculum source do not influence the growth of palm tree seedlings, the use of spores from forest soil and from areas under the influence of E. edulis roots increase the amount of spores in the seedlings substrate.

3. Arbuscular mycorrhizal fungi inoculation provides greater accumulation of nutrients in the shoot and root of E. edulis seedlings.

\section{ACKNOWLEDGMENTS}

The authors are grateful to the Conselho Nacional de Desenvolvimento Científico e Tecnológico (CNPq), Coordenação de Aperfeiçoamento de Pessoal de Nível Superior (Capes) and Instituto Federal do Sudeste de Minas (IF Sudeste MG, Campus Rio Pomba).

\section{REFERENCES}

ANDREAZZI, C. S.; PIRES, A. S.; FERNANDEZ, F. A. S. Mamíferos e palmeiras neotropicais: interações em paisagens fragmentadas. Oecologia Brasiliensis, v. 13, n. 4, p. 554-574, 2009.

ANTONIOLLI, Z. I. et al. Spore communities of arbuscular mycorrhizal fungi and mycorrhizal associations in different ecosystems, South Australia. Revista Brasileira de Ciências do Solo, v. 26, n. 3, p. 627-635, 2002.

BARROSO, R. M.; REIS, A.; HANAZAKI, N. Etnoecologia e etnobotânica da palmeira Juçara (Euterpe edulis Martius) em comunidades quilombolas do Vale do Ribeira, São Paulo. Acta Botanica Brasilica, v. 24, n. 2, p. 518-528, 2010.

BOVI, M. L. A. Palmito-açaí. In: INSTITUTO AGRONÔMICO. Instruções agrícolas para as principais culturas econômicas. Campinas: IAC, 1998. p. 264-268.

BOVI, M. L. A.; CARDOSO, M. G. Conservação de sementes de palmiteiro (Euterpe edulis Mart.). Bragantia, v. 37, n. 1, p. 65-71, 1978.

BRASIL. Ministério do Meio Ambiente. Instrução normativa $\mathrm{n}^{\circ} 06$, de 23 de setembro de 2008. Lista oficial das espécies da flora brasileira ameaçadas de extinção. 
2008. Available at: <http://www.mma.gov.br/estruturas/ ascom_boletins/_arquivos/83_19092008034949.pdf $>$. Acess on: 22 Jun. 2015.

BRASIL. Ministério do Meio Ambiente. Portaria MMA $\mathrm{n}^{\circ}$ 443, de dezembro de 2014. Lista oficial das espécies da flora brasileira ameaçadas de extinção. 2014. Available at: <http://cncflora.jbrj.gov.br/portal/static/pdf/portaria mma_443_2014.pdf $>$. Acess on: 14 May 2016.

CALVI, G. P.; PINÃ-RODRIGUES, F. C. M. Fenologia e produção de sementes de Euterpe edulis - Mart. em trecho de floresta de altitude no município de Miguel Pereira - RJ. Revista Universidade Rural, v. 25, n. 1, p. 33-40, 2005.

CARVALHO, P. E. R. Espécies florestais brasileiras: recomendações silviculturais, potencialidades e uso da madeira. Colombo: Embrapa Florestas, 1994.

CEMBRANELI, F.; FISCH, S. T. V.; CARVALHO, C. P. Exploração sustentável da palmeira Euterpe edulis Mart. no bioma Mata Atlântica, Vale do Paraíba - SP. Revista Ceres, v. 56, n. 3, p. 233-240, 2009.

CHU, E. Y. The effects of arbuscular mycorrhizal fungi inoculation on Euterpe oleracea Mart. (açaí) seedlings. Pesquisa Agropecuária Brasileira, v. 34, n. 6, p. 1019-1024, 1999.

CZERNIAK, M. J.; STÜMER, S. L. Produção de inoculante micorrízico on farm utilizando resíduos da indústria florestal. Revista Brasileira de Ciências do Solo, v. 38, n. 6, p. 1712-1721, 2014.

DOUDS JR., D. D. et al. Choosing a mixture ratio for the on-farm production of AM fungus inoculum in mixtures of compost and vermiculite. Compost Science and Utilization, v. 16, n. 1, p. 52-60, 2008.

DOUDS JR., D. D.; MILNER, P. D. Biodiversity of arbuscular mycorrhizal fungi in agroecosystems. Agriculture, Ecosystems and Environment, v. 74, n. 1-3, p. 77-93, 1999.

EMPRESA BRASILEIRA DE PESQUISA AGROPECUÁRIA (Embrapa). Centro Nacional de Pesquisa de Solos. Manual de métodos de análise do solo, plantas e fertilizantes. Brasília, DF: Embrapa, 2009.

FANELLI, L. A. et al. Incentivos e impedimentos na conservação de Euterpe edulis Mart. em comunidades quilombolas do Vale do Ribeira. Revista Brasileira de Agroecologia, v. 7, n. 2, p. 51-62, 2012.

FAVRETO, R.; MELLO, R. S. P.; BAPTISTA, L. R. M. Growth of Euterpe edulis Mart. (Arecaceae) under forest and agroforestry in southern Brazil. Agroforest System, v. 80, n. 2, p. 303-313, 2010.

GALETTI, M.; FERNANDEZ, J. C. Palm heart harvesting in the Brazilian Atlantic Forest: changes in industry structure and the illegal trade. Journal of Applied Ecology, v. 35, n. 2, p. 294-301, 1998.

GAZEY, C.; ABBOTT, L. K.; ROBSON, A. D. The rate of development of mycorrhizas affects the onset of sporulation and production of external hyphae by 2 species of Acaulospora. Mycological Research, v. 96, n. 8, p. 643-650, 1992.

GERDEMANN, J. W.; NICOLSON, T. H. Spores of mycorrhizal Endogone species extracted from soil by wet sieving and decanting. Transactions of the British Mycological Society, v. 46, n. 2, p. 235-244, 1963.

GIANINAZZI, S. et al. Agroecology: the key role of arbuscular mycorrhizas in ecosystems services. Mycorrhiza, v. 20, n. 20, p. 519-530, 2010.

LORENZI, H. et al. Palmeiras no Brasil: nativas e exóticas. São Paulo: Plantarum, 1996.

MAHERALI, H.; KLIRONOMOS, J. N. Influence of phylogeny on fungal community assembly and ecosystem functioning. Science, v. 316, n. 5832, p. 1746-1748, 2007.

MARTINS, S. V.; SOUZA, M. N. Cultivo do palmiteiro Juçara (Euterpe Edulis Mart.): produção de palmito e restauração florestal. Viçosa: Aprenda Fácil, 2009.

MARTINS-COORDER, M. P.; SALDANHA, C. W. Germinação de sementes e crescimento de plântulas de diferentes progênies de Euterpe edulis Mart. Revista Árvore, v. 30, n. 5, p. 693-699, 2006.

MEDINA, J. M et al. Fungos micorrízicos arbusculares em Euterpe edulis Martius (palmeira Juçara) no município de Rio Pomba/MG. Vértices, v. 14, special n., p. 159-167, 2012.

OLIVEIRA JÚNIOR, C. J. F.; NEVES, Y. T. R.; JUNQUEIRA, P. S. População Caiçara, Mata Atlântica e situação do palmito-Juçara (Euterpe edulis Mart.) na região do rio Una da Aldeia (Iguape - SP), entorno da Estação Ecológuca Jureia-Itatins. Revista Árvore, v. 34, n. 6, p. 1065-1073, 2010.

PARNISKE, M. Arbuscular mycorrhiza: the mother of plant root endosymbioses. Nature Reviews Microbiology, v. 6, n. 10 , p. $763-775,2008$.

R CORE TEAM. $R$ : a language and environment for statistical computing. Viena: R Foundation for Statistical Computing, 2014.

RIBEIRO, M. C. et al. The Brazilian Atlantic Forest: how much is left, and how is the remaining forest distributed?: implications for conservation. Biological Conservation, v. 142, n. 6, p. 1141-1153, 2009.

SGROTT, A. F. et al. Arbuscular mycorrhizal inoculation increases biomass of Euterpe Edulis and Archontophoenix Alexandrae after two years under field conditions. Revista 
Brasileira de Ciências do Solo, v. 36, n. 4, p. 1103-1112, 2012.

SILVA, E. M. R. et al. Ocorrência e efetividade de fungos micorrízicos em plantas cultivadas. Seropédica: Embrapa, 1998.

SMITH, S. E.; READ, D. J. Mycorrhizal symbiosis. London: Academic Press, 1997.
TAHAT, M. M.; KAMARUZAMAN, S.; OTHMAN, R. Mycorrhizal fungi as a biocontrol agent. Plant Pathology Journal, v. 9, n. 4, p. 198-207, 2010.

WEHNER, J. et al. Plant pathogen protection by arbuscular mycorrhizas: a role for fungal diversity? Pedobiologia, v. 53, n. 3, p. 197-201, 2010 . 